\title{
Perkembangan Otak Anak Usia Dini
}

\author{
La Ode Anhusadar \\ Dosen Prodi PGRA Jurusan Tarbiyah STAIN Sultan Qaimuddin Kendari
}

\begin{abstract}
Abstrak
Anak yang terlahir sehat tanpa gangguan secara fisik maupun gangguan neurologis merupakan dambaan setiap orang tua. Agar dapat mencapai hal tersebut tentu terdapat berbagai kriteria yang harus terpenuhi dalam pertumbuhan dan perkembangan anak sejak dari masa janin. Salah satunya adalah bagaimana membentuk otak dengan baik dan tepat, karena kemampuan otak dapat mempengaruhi kualitas hidup seseorang agar dapat menjadi manusia seutuhnya. Perkembangan otak sebagaimana tumbuh kembang anak pada umumnya dipengaruhi oleh faktor genetik dan faktor lingkungan baik lingkungan internal (faktor-faktor yang terdapat dalam diri janin atau anak itu sendiri), maupun lingkungan eksternal (faktor di luar anak). Faktor eksternal misalnya kondisi ibu hamil, lingkungan tempat tinggal, pola asuh (otoriter, partipatif, demokratis atau permisif), pola makan, pemberian ASI yang adekuat, asupan nutrisi dan mikronutrien penting seperti iodium, zink, selenium, zat besi, serta kecukupan oksigen.
\end{abstract}

Kata kunci: Perkembangan Otak

\begin{abstract}
Children are born healthy without any physical disorder or neurological disorder is the desire of every parent. In order to achieve this, of course there are various criteria that must be met in the growth and development of children from fetal life. One of them is how to establish good and right brain, because the brain's ability to influence the quality of life in order to become fully human. Brain development as well as growth and development of children in general is influenced by genetic factors and environmental factors both internal environment (the factors contained within the fetus or the child itself), as well as the external environment (factors outside the child). External factors such as the condition of pregnant women, neighborhood, parenting (authoritarian, participatory, democratic or permissive), diet, adequate breastfeeding, nutrition and essential micronutrients such as iodine, zinc, selenium, iron, as well as the adequacy of oxygen .
\end{abstract}

Keywords : Brain Development

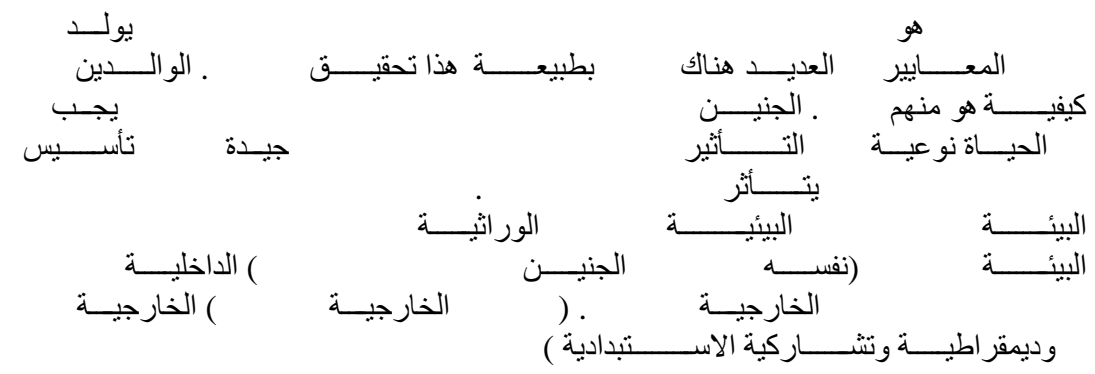




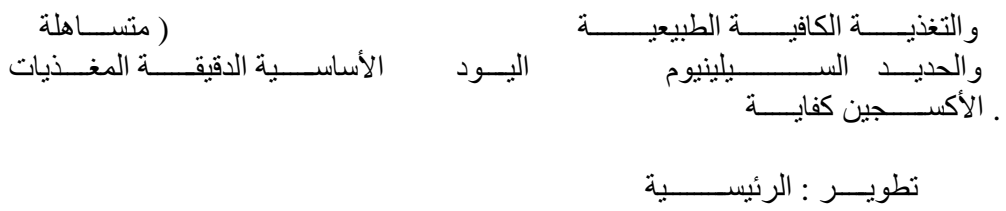

\section{A. Hakikat dan Prinsip Perkembangan Otak}

Otak yang dalam bahasa Inggris disebut encephalon adalah pusat (central nervous system, CNS) pada vertebrata dan banyak invertebrata lainnya. Otak manusia adalah struktur pusat pengaturan yang memiliki volume sekitar $1.350 \mathrm{cc}$ dan terdiri atas 100 juta sel saraf atau neuron. Otak mengatur dan mengkoordinir sebagian besar, gerakan, perilaku dan fungsi tubuh homeostasis seperti detak jantung, tekanan darah, keseimbangan cairan tubuh dan suhu tubuh. Otak manusia bertanggung jawab terhadap pengaturan seluruh badan dan pemikiran manusia. Oleh karena itu terdapat kaitan erat antara otak dan pemikiran. ${ }^{1}$

Otak terbentuk dari dua jenis sel yaitu glia dan neuron. Glia berfungsi untuk menunjang dan melindungi neuron, sedangkan neuron membawa informasi dalam bentuk pulsa listrik yang di kenal sebagai potensi aksi. Mereka berkomunikasi dengan neuron yang lain dan keseluruh tubuh dengan mengirimkan berbagai macam bahan kimia yang disebut neurotransmiter. Neurotransmiter ini dikirimkan pada celah yang dikenal sebagai sinapsis. ${ }^{2}$

Neuron otak mengandung dua jenis asam lemak PUFA (polyunsaturated fatty acids), yaitu asam arakidonat (AA) dan asam dokosaheksaenoat (DHA) yang terletak pada posisi sn2 dari molekul fosfogliserida dalam membran sel neuron. ${ }^{[2]}$ PUFA dapat terlepas dari fosfogliserida oleh stimulasi fosfolipase PLA-2. Molekul AA yang terlepas akan diproses oleh enzim siklo oksigenase menjadi prostaglandin dan tromboksana, atau diproses oleh enzim 5-lipo oksigenase menjadi lipoksin. Baik AA maupun DHA dapat diproses oleh enzim lipo oksigenase guna membentuk senyawa turunan hidroksi dan leukotriena. ${ }^{3}$

\footnotetext{
${ }^{1}$ Wikipedia. Tersedia:http://www.Otak - Wikipedia bahasa Indonesia, ensiklopedia bebas.htm [22-03-2013.] [04-09-2013].

${ }^{2}$ Ibid,.

${ }^{3}$ Ibid,.
} 


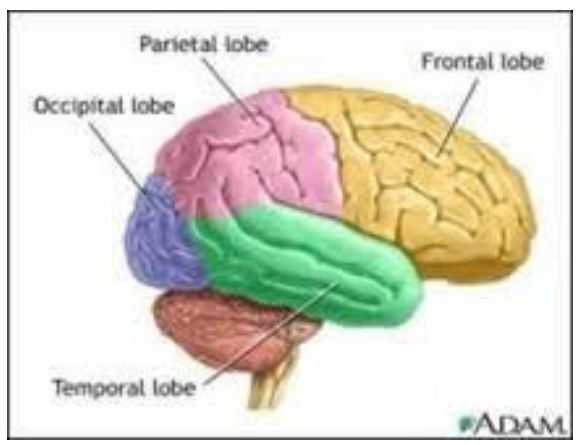

Gambar 1. 4 lobus otak

Perkembangan otak anak yang sedang tumbuh melalui tiga tahapan, mulai dari otak primitif (action brain), otak limbik (feeling brain), dan akhirnya ke neocortex (atau disebut juga thought brain, otak pikir). Meski saling berkaitan, ketiganya punya fungsi sendirisendiri: ${ }^{4}$

1. Otak primitif mengatur fisik kita untuk bertahan hidup, mengelola gerak refleks, mengendalikan gerak motorik, memantau fungsi tubuh, dan memproses informasi yang masuk dari pancaindera. Saat menghadapi ancaman atau keadaan bahaya, bersama dengan otak limbik, otak primitif menyiapkan reaksi "hadapi atau lari" (fight or flight response) bagi tubuh.

2. Otak limbik memproses emosi seperti rasa suka dan tidak suka, cinta dan benci. Otak ini sebagai penghubung otak pikir dan otak primitif. Maksudnya, otak primitif dapat diperintah mengikuti kehendak otak pikir, di saat lain otak pikir dapat "dikunci" untuk tidak melayani otak limbik dan primitif selama keadaan darurat, yang nyata maupun yang tidak. Sedangkan otak pikir, yang merupakan bentuk daya pikir tertinggi dan bagian otak yang paling objektif, menerima masukan dari otak primitif dan otak limbik. Namun, ia butuh waktu lebih banyak untuk memproses informasi, termasuk image, dari otak primitif dan otak limbik.

3. Otak pikir juga merupakan tempat bergabungnya pengalaman, ingatan, perasaan, dan kemampuan berpikir untuk melahirkan gagasan dan tindakan.

Myelinasi saraf otak berlangsung secara berurutan, mulai dari otak primitif, otak limbik, dan otak pikir. Jalur syaraf yang makin sering digunakan membuat myelin makin menebal. Makin tebal

\footnotetext{
4 Agus Surono. Tersedia:http://www.Tiga tahap perkembangan otak- Intisari Online.htm [Tiga Tahap Perkembangan Otak. [19-07-2011] [04-09-2013].
} 
myelin, makin cepat impuls syaraf atau perjalanan sinyal sepanjang "urat" syaraf. Karena itu, anak yang sedang tumbuh dianjurkan menerima masukan dari lingkungannya sesuai dengan perkembangannya. Di samping itu, anak juga membutuhkan pengalaman yang merangsang pancaindera. Namun, indera mereka perlu dilindungi dari rangsangan yang berlebihan karena anak-anak itu ibarat spon. Rangsangan dan perkembangan indera itu pada gilirannya akan mengembangkan bagian tertentu dari otak primitif yang disebut reticular activating system(RAS). RAS ini pintu masuk tempat kesan yang ditangkap setiap indera saling berkoordinasi sebelum diteruskan ke otak pikir. RAS merupakan wilayah di otak yang membuat kita mampu memusatkan perhatian. ${ }^{5}$

Kurangnya stimulasi, atau sebaliknya stimulasi yang berlebihan, ditambah lagi dengan gerakan motorik kasar dan halus yang tidak berkembang secara baik, bisa menyebabkan rusaknya perhatian terhadap lingkungan. Sebelum anak berusia empat tahun, otak primitif dan otak limbik sudah $80 \%$ termyelinasi. Setelah umur 6 - 7 tahun myelinasi bergeser ke otak pikir. Awalnya dari belahan otak kanan yang antara lain bertugas merespons citra visual. Ketika menonton $\mathrm{TV}$, belahan otak kanan inilah yang paling dominan kerjanya. Sedangkan ketika membaca, menulis, dan berbicara, belahan otak kiri yang dominan. Tugas utama otak kiri ialah berpikir secara analitis dan menyusun argumen logis langkah demi langkah. Ia menganalisis suara dan makna bahasa (misalnya, kemampuan mencocokkan suara dengan alfabet), juga mengelola keterampilan otot halus. Kedua belahan otak itu dijembatani oleh bundel "urat" syaraf yang disebut corpus collosum. Sisi kanan dan kiri tubuh saling berkoordinasi melalui jembatan ini. ${ }^{6}$

Aktivitas motorik kasar seperti lompat tali, memanjat, lari, serta aktivitas motorik halus macam menggambar, merenda, membuat origami, dan bikin kue merupakan akitivitas penting bagi proses myelinasi $C$. collosum. Jalur ini memungkinkan kemampuan berpikir analitis (otak kiri) dan intuitif (otak kanan) untuk saling mempengaruhi. Sejumlah ahli neuropsikologi percaya, buruknya perkembangan jembatan ini mempengaruhi komunikasi efektif antara belahan otak kanan dan kiri. ${ }^{7}$

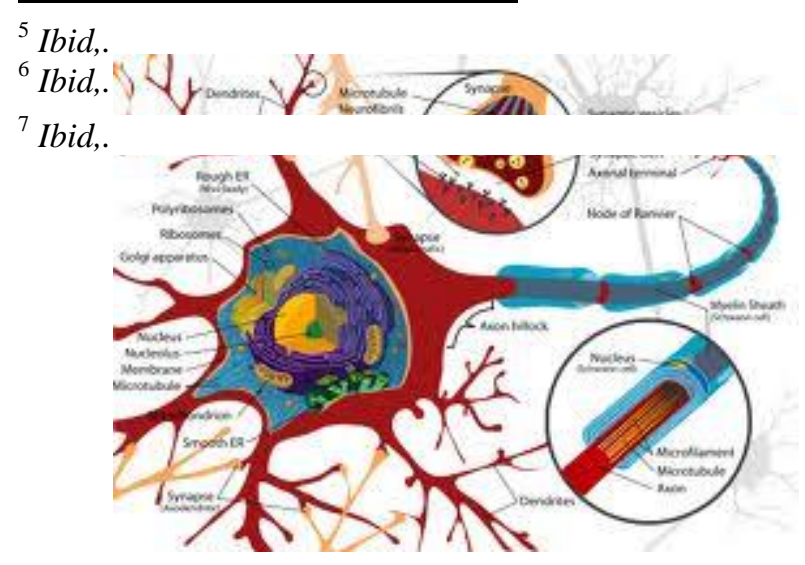




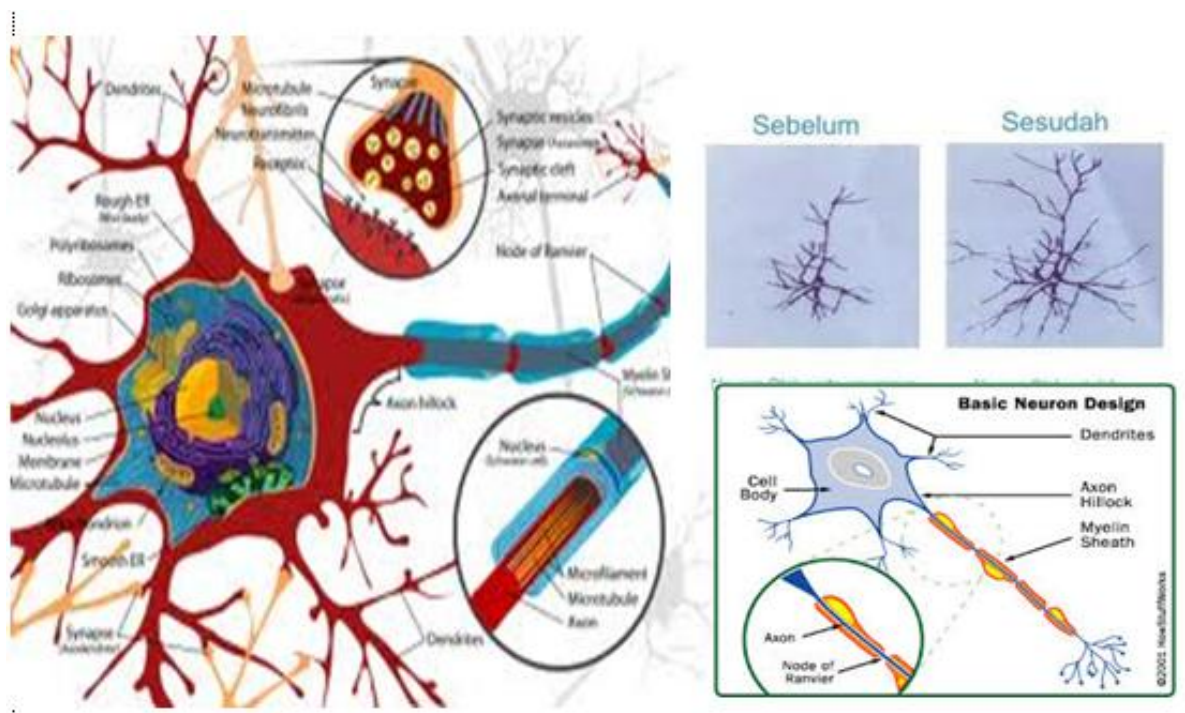

Gambar 2. Neuron Otak

\section{Perkembangan Otak Masa Janin}

Sejak kandungan ibu berusia 2-3 bulan, sel saraf otak janin sudah berkembang, dan terus berlanjut hingga terbentuk berbagai struktur otak sampai nyaris sempurna menjelang kelahiran. Perkembangan sel-sel otak janin dibentuk sejak 3 - 4 bulan di dalam kandungan ibu, kemudian setelah lahir sampai umur 3 - 4 tahun jumlahnya bertambah dengan cepat mencapai milyaran sel, tetapi belum ada hubungan antar sel-sel tersebut. Sel-sel saraf otak balita berkembang sangat pesat. Hal ini dapat diketahui dari penambahan berat otak ataupun lingkar kepala balita.
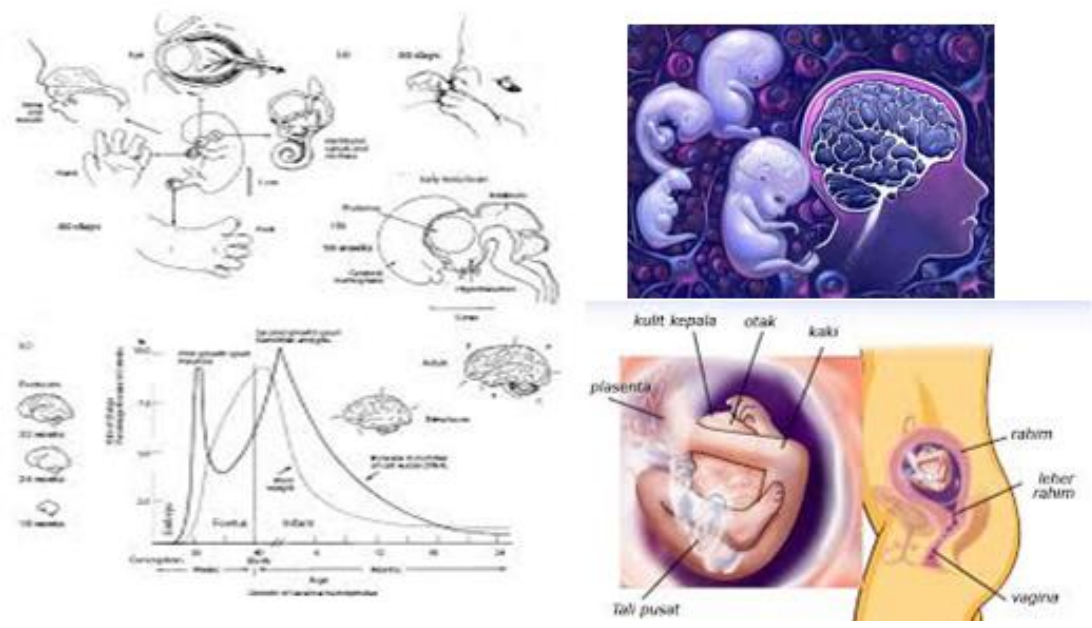

Gambar 3. Perkembangan Otak Janin 


\section{Perkembangan Otak Masa Bayi}

Perkembangan otak bayi setelah dilahirkan, rangkaian penglihatan, bau, suara, sentuhan, bahasa, dan kontak mata membantu membentuk hubungan neural otak. Otak bayi menunggu pengalaman untuk menentukan bagaimana hubungan dibentuk. Pada saat bayi yang baru lahir sekitar 25\% dari berat otak dewasa. Pada tahun kedua, otak sekitar $75 \%$ berat otak dewasa. Dua perkembangan kunci selama 2 tahun pertama mencakup selubung myelin (lapisan sel lemak yang mempercepat impuls elektrik sepanjang akson) dan ikatan sinapsis. ${ }^{8}$ Puncak kelebihan produksi sinapsis di daerah yang berhubungan dengan visual terjadi sekitar bulan keempat setelah kelahiran, diikuti oleh pemutusan secara bertahap hingga tahun-tahun pertengahan dan akhir prasekolah.

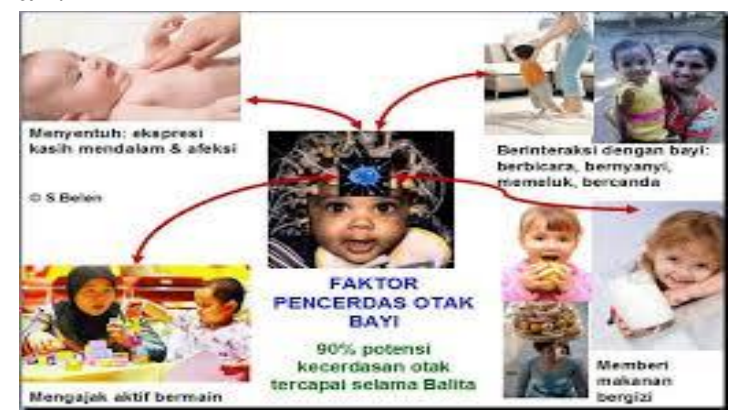

Gambar 4. Perkembangan Otak Bayi

Kelebihan produksi dan pemutusan yang hampir sama terjadi agak kemudian di daerah otak yang terlibat dalam pendengaran dan bahasa. Di korteks prefrontal (daerah otak di mana berpikir tingkat tinggi dan pengaturan diri terjadi), puncak kelebihan produksi terjadi tidak lama setelah usia 3 tahun. ${ }^{9}$ Saat lahir, hemisfer telah mulai mengkhususkan diri, bayi yang baru lahir menunjukkan aktivitas listrik yang lebih besar di hemisfer kiri daripada di hemisfer kanan saat mereka mendengarkan suara bicara. Pada saat 2 bulan, pusat kendali motorik otak berkembang hingga titik bayi mampu secara tiba-tiba meraih dan menggenggam objek yang dekat. Usia 4 bulan hubungan neural yang diperlukan untuk persepsi kedalaman mulai terbentuk. Usia 12 bulan pusat bicara otak diseimbangkan untuk menghasilkan kata pertama. Aktivitas listrik otak terjadi dari sekitar

\footnotetext{
${ }^{8}$ John W Santrock. Perkembangan Anak. Jakarta: Erlangga, 2007. H.171-172

${ }^{9}$ Ibid,. H. 172-174
} 
usia 1 1/2 hingga 2 tahun, gelombang aktivitas ini dihubungkan dengan peningkatan dalam perkembangan konseptual dan bahasa. ${ }^{10}$
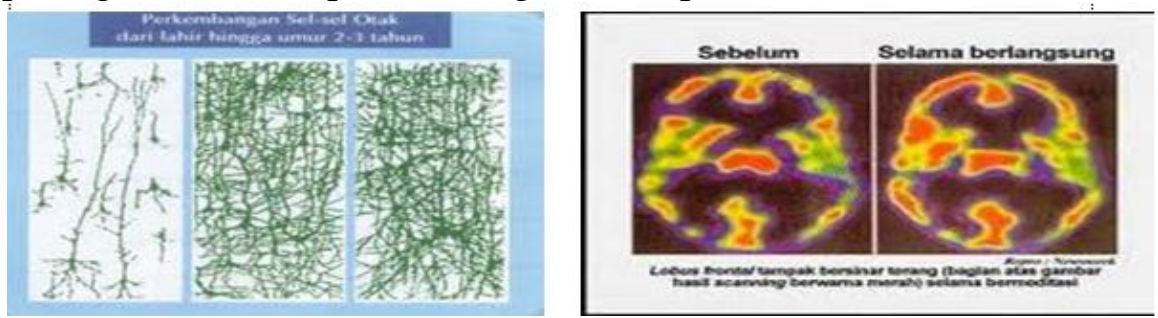

Gambar 5. Penyebaran Dendrit

\section{Perkembangan Otak Masa Kanak-kanak}

Sepanjang masa kanak-kanak, otak tidak tumbuh secepat masa bayi. Meskipun demikian, otak dan kepala masih tumbuh lebih cepat daripada anggota tubuh lainnya. Beberapa peningkatan otak dalam ukuran disebabkan oleh myelinasi dan beberapa disebabkan peningkatan dalam jumlah dan ukuran dendrit. Dari usia 3 hingga 6 tahun, pertumbuhan yang paling cepat terjadi di area lobus frontal yang terlibat dalam perencanaan dan pengaturan tindakan baru dan dalam mempertahankan perhatian terhadap tugas. Usia 6 hingga masa puber, pertumbuhan yang paling dramatis terjadi dalam lobus temporal dan parietal, khususnya pada area yang memainkan peran utama dalam bahasa dan hubungan spasial. Konsentrasi dopamine dalam otak anak biasanya meningkat secara signifikan dari usia 3 hingga 6 tahun, dihubungkan dengan keterampilan kognitif anak yang sedang berkembang.

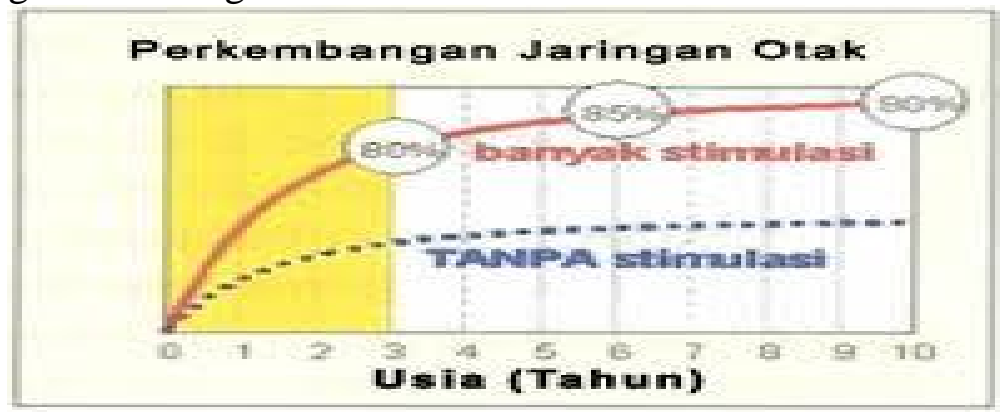

Gambar 6. Perkembangan Jaringan Otak Anak

\section{B. Gangguan Perkembangan Otak Masa Janin Sampai Usia Anak-Anak}

Secara garis besar gangguan perkembangan otak dapat dikelompokkan Jones sebagai berikut: ${ }^{11}$

\footnotetext{
${ }^{10}$ Ibid,. H. 174
} 
1. Gangguan anatomi struktur otak antara lain anensefali, ensefalokel, meningokel, hidrosefali, atrofi serebri, plagiosefali, tidak terbentuknya beberapa bagian otak dansebagainya;

2. Gangguan fungsi otak dan susunan saraf pusat (SSP) meliputi antara lain gangguan perkembangan motorik kasar, motorik halus, gangguan bicara, gangguan perilaku, epilepsi, autis, ketidakmampuan intelektual, palsi serebral maupun disfungsi otak, serta Gangguan Pemusatan Perhatian dan Hiperaktif (GPPH);

3. Gangguan baik anatomis maupun fungsi yang kompleks seperti terjadinya gejala sisa pasca ensefalitis/meningo ensefalitis, ventrikulomegali, pasca hipoksik ensefalopati dan pasca cedera otak;

4. Dismorfisme antara lain sindroma Down, sindroma Neurokutan, sindroma Dunde Walker.

Melihat jenis gangguan perkembangan otak tersebut dapat diartikan bahwa gangguan perkembangan otak bisa terjadi sejak dalam kandungan sampai dewasa; berlangsung secara akut dan progresif; bisa kronis tidak progresif tetapi terjadi perubahan yang nyata atau subklinis diikuti munculnya gangguan fungsi tergantung penyebabnya. $^{12}$

Banyak faktor internal dan eksternal dari ibu hamil yang dapat berpengaruh dalam menentukan tumbuh kembang janin sehingga dapat mengganggu kesehatan bayi saat dilahirkan. Masa depan anak dan kehebatan buah hati kita ternyata sangat ditentukan sejak dini khususnya saat kehamilan, berikut adalah contoh penyebab gangguan perkembangan otak masa janin dan anak yang diakibatkan oleh faktor internal dan eksternal dari ibu hamil: ${ }^{13}$

1. Asap rokok. Bukan hanya merokok langsung secara aktif, perokok pasif atau terhirup asap rokok di lingkungan bagi ibu hamil bisa berdampak buruk. Penelitian pada anak yang terlahir dari ibu yang terpapar asap rokok selama masa kehamilan berisiko dua kali lebih tinggi mengalami gangguan perhatian dan cenderung agresif ketika mencapai usia lima tahun. Penelitian lain menyatakan bahwa merokok merupakan penyebab nomer satu dalam lahirnya

\footnotetext{
${ }^{11}$ Sunartini. Deteksi Gangguan Perkembangan Otak Dan Pengembangan Potensi Anak Dengan Kemampuan Dan Kebutuhan Khusus. Jogjakarta: Universitas Gadjah Mada Press, 2008. H.8

${ }^{12} \mathrm{Ibid}$.

13 Widodo Judarwanto. Tersedia:http://www.gangguan otak netlWaspadai 10 Kondisi Kehamilan Penyebab Gangguan Janin.htm [09-04-2013] [04-09-2013].
} 
bayi dengan kondisi buruk, seperti lahir prematur, bayi yang lahir terlalu kecil pertumbuhan terlambat, kerusakan otak, kerusakan organ tubuh yang paling parah adalah kegagalan janin atau kematian. Jika bayi yang terkontaminasi zat kimia rokok berhasil lahir, maka akan terjadi kelainan dalam perkembangan tubuh dalam hal berat serta ukuran, organ tubuh seperti paru-paru yang tidak berfungsi secara optimal serta fungsi otak yang terbelakang.

2. Flu berkepanjangan. Risiko skizofrenia atau gangguan jiwa tiga kali lipat saat ibu sakit flu selama paruh pertama kehamilan dan meningkat tujuh kali lipat jika paparan terjadi pada trimester pertama. Risiko secara keseluruhan adalah kecil, namun. Temuan menunjukkan bahwa sekitar 97\% anak lahir dari ibu yang terserang flu saat hamil beresiko skizofrenia. Meskipun peneliti tidak tahu mekanisme kerja, diduga antibodi yang dikeluarkan oleh sistem kekebalan tubuh ibu dapat mempengaruhi perkembangan otak. Ternyata flu saat hamil jangan diremehkan. Beberapa penelitian menunjukkan bahwa ibu hamil yang mengalami flu beresiko cacat janin, kanker dan Skizofrenia. Sebuah tim dari California Institute of Technology peneliti telah menemukan sebuah link yang tak terduga menghubungkan skizofrenia dan autisme pada saat kehamilan Sebuah tim dari California Institute of Technology peneliti telah menemukan sebuah link yang tak terduga menghubungkan skizofrenia dan autisme pada saat kehamilan. Efek teratogenik diduga bukan langsung dari virus influenza diduga reaksi autoimunitas dari tubuh yang berpengaruh terhadap janin. Prevalensi prevalensi lebih tinggi dari CA ditunjukkan di atas dapat dijelaskan terutama oleh demam, karena risiko ini berkurang penggunaan obat antifever. Suplementasi asam folat Periconceptional juga menunjukkan beberapa efek pencegahan untuk ini CA.

3. Kekurangan asam folat. Konsumsi asam folat yang cukup saat kehamilan merupakan kunci perkembangan dan metabolisme sel pada awal terjadinya pembuahan. Kekurangan asam folat akan menyebabkan bayi menderita spina bifida dan gangguan otak lainnya. Asam folat juga diketahui sebagai koenzim untuk produksi DNA serta meningkatkan replikasi sel. Asam folat sangat dibutuhkan justru pada saat kehamilan belum disadari, yakni pada minggu kedua sampai keempat pertumbuhan janin. Seorang perempuan usia produktif membutuhkan asam folat 400 mikrogram setiap harinya. Kita bisa mendapatkannya dari sayuran 
berdaun hijau, kacang-kacangan, buah-buahan seperti lemon, pisang, dan melon, serta produk makanan yang sudah difortifikasi.

4. Infeksi TORCH. TORCH adalah istilah yang mengacu kepada infeksi yang disebabkan oleh (Toksoplasma, Rubella, Cytomegalovirus (CMV) dan Herpes simplex virus II (HSV-II) dalam wanita hamil. Infeksi TORCH ini sering menimbulkan berbagai masalah kesuburan (fertilitas) baik pada wanita maupun pria sehingga menyebabkan sulit terjadinya kehamilan. Infeksi TORCH bersama dengan paparan radiasi dan obat-obatan teratogenik dapat mengakibatkan kerusakan pada embrio. Beberapa kecacatan janin yang bisa timbul akibat TORCH yang menyerang wanita hamil antara lain kelainan pada saraf, mata, kelainan pada otak, paru-paru, mata, telinga, terganggunya fungsi motorik, hidrosepalus, dan lain sebagainya.

5. Konsumsi antidepresan. Lebih dari 13 persen wanita mengonsumsi antidepresan saat hamil. Mengonsumsi salah satu jenis antidepresan yaitu selective serotonin reuptake inhibitor (SSRI) ketika hamil dikaitkan dengan tingginya risiko keguguran, lahir cacat, persalinan prematur dan gangguan perilaku pada bayi, termasuk autisme. Padahal 3 persen wanita yang mengonsumsi antidepresan selama hamil dilaporkan menggunakan SSRI. Antidepresan memang memberikan manfaat nyata bagi wanita dengan gangguan kesehatan mental, sebaiknya mereka konsumsi sebelum memutuskan untuk hamil.

6. Kekurangan yodium. Defisiensi atau kekurangan yodium saat kehamilan dapat melahirkan kretine endemik serta gangguan kognitif dan psikomotorik yang bersifat menetap. Namun kerusakan ini dapat dicegah hanya dengan memberikan masukan yodium yang cukup pada menu makanan sehari-hari selama kehamilan. Kretin endemic merupakan bentuk kerusakan otak derajat berat [major brain damage] akibat defisiensi yodium selama kehamilan. Manifestasi klinik secara klasik adalah kretin nervosa, miksedematosa atau campuran keduanya. Patogenisnya adalah akibat hipotiroidisme maternal dan fetal yang mempengaruhi perkembangan otak janin.

7. Kekurangan vitamin D. Rendahnya kadar 'vitamin sinar matahari' selama hamil akan menyebabkan gangguan kesehatan, baik pada sang ibu maupun si anak. Sebuah kajian terhadap 30 penelitian mengungkapkan rendahnya kadar vitamin D dalam tubuh seorang ibu dikaitkan dengan tingginya risiko diabetes gestasional, pre- 
eclampsia dan berat lahir yang rendah. Vitamin D berpengaruh sangat positif bagi ibu hamil dan calon bayinya. Selain fungsinya untuk mendukung pertumbuhan tulang, bayi yang lahir dari ibu yang cukup mengonsumsi vitamin D selama hamil cenderung lebih cerdas. Demikian kesimpulan penelitian di Spanyol yang melibatkan 2000 ibu dan bayi mereka. Kekurangan vitamin D diketahui terkait dengan perkembangan mental dan kemampuan gerak bayi. Kelompok wanita yang terancam defisiensi vitamin D pada umumnya adalah mereka yang kegemukan atau obesitas, berasal dari sosial ekonomi rendah, dan wanita yang kulitnya lebih gelap. Faktor geografi juga berpengaruh, mereka yang jarang terpapar sinar matahari juga memiliki level vitamin D lebih rendah.

8. Paparan polusi udara. Polusi udara yang disebabkan oleh lalu lintas, industri hingga debu selama masa kehamilan akan meningkatkan risiko berat lahir bayi rendah. Ada dua jenis polusi kendaraan bermotor yang berdampak pada pertumbuhan janin, yaitu partikel hitam dan nitrogen dioksida. Dua jenis polusi itu bisa masuk paru-paru dan mengganggu fungsi organ itu. Hasil studi di AS yang dipublikasikan dalam Jurnal Epidemiologi dan Kesehatan Komunitas sebagaimana dikutip situs BBC menyebutkan, tingginya paparan polusi dari asap kendaraan bermotor pada ibu pada awal dan akhir kehamilan bisa menyebabkan janin tidak tumbuh baik sehingga bayi lahir dengan berat badan rendah.

Dari beberapa contoh faktor gangguan perkembangan otak pada janin dan anak akan menyebabkan gangguan otak, diantaranya: ${ }^{14}$

\section{Celebral Palsy (CP)}

$\mathrm{CP}$ merupakan gangguan sistem motorik akibat adanya kerusakan di otak. Kondisi ini bisa terjadi sejak janin dalam kandungan, maupun saat bayi sudah lahir. Tidak mudah mendiagnosis $\mathrm{CP}$ secara tepat sejak dini. Sebab itu, orangtua harus selalu mengamati perkembangan anak. Bila dikenali adanya kelainan, sebaiknya orangtua segera memeriksakannya ke dokter. Proses kelahiran yang tidak sempurna, contohnya bayi kekurangan oksigen, divakum, lalu bayi yang lahir dengan berat badan rendah, dan bayi dengan bilirubin tinggi (bayi kuning), dapat menyebabkan timbulnya $\mathrm{CP}$. $\mathrm{CP}$ dapat

\footnotetext{
14 Medicastore. Tersedia:http:www.gangguan otak net Informasi Kelainan Otak Bawaan - medicastore.com.htm [2010] [04-09-2013]
} 
dideteksi sejak masa-masa awal tumbuh-kembang bayi, misalnya dengan mengamati gejala atau fungsi refleksnya. Normalnya, bayi berusia 3-4 bulan akan meraih mainannya, di usia 5 bulan tangannya akan menyambut ke atas bila akan diangkat, usia 6-7 bulan sudah mampu duduk, dan usia 10-14 bulan biasanya mulai bisa berjalan. Bayi dengan kelainan CP tidak memiliki fungsi refleks itu.

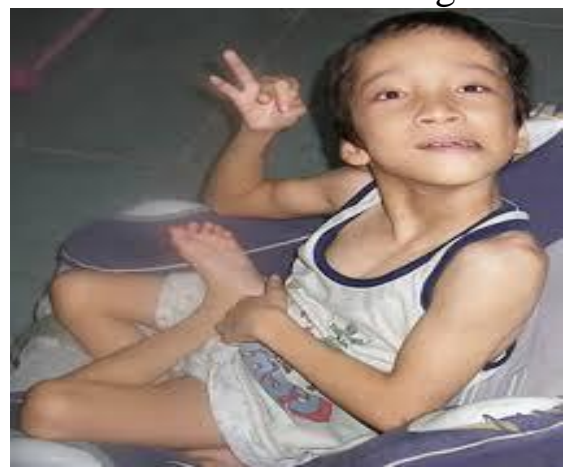

\section{Meningitis}

Gambar 7. Anak Penderita CP

Meningitis atau radang otak adalah radang yang terjadi pada membran pelindung sistem saraf pusat. Dapat ditimbulkan oleh virus, bakteri, ataupun jamur yang menyebar masuk ke dalam darah dan berpindah ke cairan otak. Bakteri yang dapat mengakibatkan meningitis antara lain Streptococcus pneumoniae, Neisseria meningitidis, Haemophilus influenzae, dan Mycobacterium tuberculosis. Jika dibiarkan, penyakit ini dapat menimbulkan kerusakan otak, kehilangan pendengaran, berkurangnya kemampuan belajar, dan kematian. Gejalanya antara lain demam, sakit kepala, otot leher kaku, hingga berjam-jam mual serta muntah.

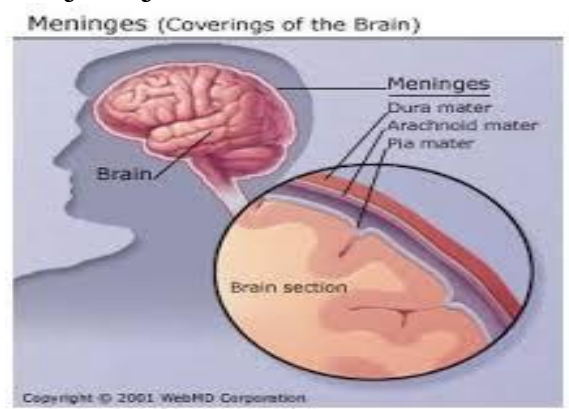

\section{Kanker Otak}

Gambar 8. Anak Penderita Menginitis

Penyakit ini disebabkan pertumbuhan sel-sel abnormal di otak yang makin lama makin membesar. Sel kanker ini bisa berasal dari 
otak, tetapi bisa pula merupakan penyebaran kanker dari organ lain melalui pembuluh darah. Tumor ganas ini berkembang secara cepat. Kanker ini makin lama makin membesar, kemudian menekan otak dan tulang tengkorak

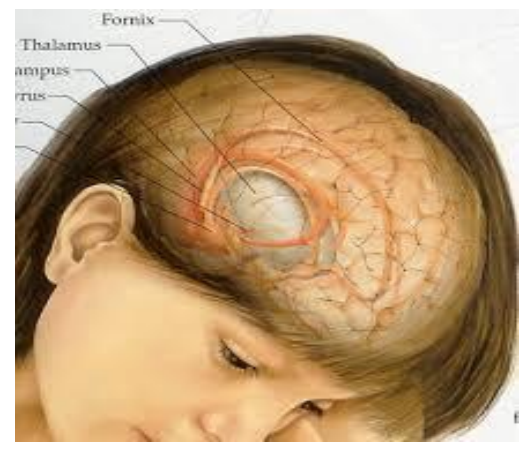

Gambar 9. Anak Penderita Kanker Otak

\section{Penanggulangan Gangguan Perkembangan Otak Masa Janin Sampai Usia Anak-Anak}

Untuk mencegah gangguan perkembangan otak tersebut di atas, banyak hal yang dapat dilakukan baik dari persiapan kedua orangtua saat akan melakukan persiapan memiliki anak, kondisi saat ibu hamil, maupun menjaga dan melindungi kesehatan anak. Penanggulangan gangguan perkembangan otak diantaranya dapat dilakukan dengan cara:

1. Sebagai calon orangtua, dalam mempersiapkan kehadiran calon anak, suami isteri hendaknya memiliki kesehatan yang baik, dengan menjaga asupan nutrisi gizi yang tepat dan seimbang.

2. Melakukan pemeriksaan kehamilan atau ante natal care (ANC) sangat disarankan bagi para ibu hamil untuk memonitor kesehatan ibu dan janin dalam kandungan. WHO menyarankan agar melakukan pemeriksaan kehamilan setiap 4 minggu sekali dari saat pemeriksaan kehamilan pertama kali hingga usia kehamilan 28 minggu, setiap 2 minggu sekali dari usia kehamilan 28-36 minggu dan setiap satu minggu sekali dari usia kehamilan 36 minggu hingga waktunya melahirkan. Pemeriksaan kehamilan minimal dilakukan sebanyak 4 kali yaitu $:{ }^{15}$

a. Pemeriksaan kehamilan pertama yaitu pemeriksaan kehamilan saat usia kehamilan antara 0-3 bulan. Memang biasanya ibu tidak menyadari kehamilan saat awal masa kehamilan, tetapi sangat

\footnotetext{
${ }^{15}$ httplgangguan otak netlWaspadai 10 Kondisi Kehamilan Penyebab Gangguan Janin.htm [04-09-2013].
} 
diharapkan agar kunjungan pertama kehamilan dilakukan sebelum usia kehamilan < 12 minggu. Pemeriksaan kehamilan ini cukup dilakukan sekali dan mungkin berlangsung 30-40 menit.

b. Pemeriksaan kehamilan kedua yaitu pemeriksaan kehamilan saat usia kehamilan antara 4-6 bulan. Biasanya kunjungan kehamilan dilakukan sebelum usia kehamilan mencapai 26 minggu. Pemeriksaan ini mungkin berlangsung 20 menit saja.

c. Pemeriksaan kehamilan ketiga yang dilakukan saat usia kehamilan mencapai 32 minggu.

d. Pemeriksaan kehamilan keempat. Ini merupakan pemeriksaan kehamilan terakhir dan dilakukan pada usia kehamilan antara 3236 minggu.

3. Menghindari penggunaan bahan kimia dan paparan radiasi kimia berpotensi besar terhadap kerusakan otak seseorang. Bahan kimia yang akrab dengan kehidupan sehari-hari adalah vinil klorida yang digunakan dalam plastik, formalin yang digunakan sebagai pengawet, dan acrylontrile digunakan dalam industri tekstil. Pancaran radiasi dari reaktor nuklir juga dapat menyebabkan kanker otak. Orang yang pekerjaannya mengharuskan untuk berinteraksi dengan bahan kimia dan nuklir, harus rutin melakukan pengujian terhadap kanker otak ke dokter.

4. Tidak Mengkonsumsi Narkoba dan Rokok. Dengan gemar merokok atau memakai narkoba otak akan rusak dan kehilangan fungsi-fungsinya. Selain itu otak jadi rentan terserang berbagai penyakit mulai dari yang ringan hingga yang berat. Ada perokok berat yang apabila tidak merokok maka dia tidak dapat berpikir dengan baik, namun semua itu hanya omong kosong yang merupakan sugesti saja. Hati-hati dan waspada pula dengan zat adiktif dan zat aditif yang dapat merusak otak kita.

5. Tidur Mengistirahatkan Otak. Otak kita butuh istirahat yang cukup setelah seharian melakukan aktivitas baik yang ringan maupun yang berat. Sebaiknya jangan terlalu banyak berpikir yang beratberat yang membutuhkan konsentrasi dan daya kerja otak yang maksimal. Istirahat otak bisa dengan melakukan sesuatu yang rileks seperti tidur-tiduran, dengan musik ringan, ngobrol sama teman dekat, nonton film komedi, dsb. Dengan tidur yang cukup selama 6 sampai 8 jam, maka otak akan dapat digunakan dengan maksimal.

6. Makanlah makanan yang bergizi dan cukup karena otak manusia membutuhkan suplai nutrisi yang cukup untuk melakukan 
pekerjaan dan untuk tumbuh berkembang. Biasakanlah sarapan setiap pagi dengan makanan yang tidak terlalu berat tetapi cukup gizinya. Jangan terlalu banyak makan sehingga kegemukan yang dapat menyumbat pembuluh otak. Konsumsi gula pun jangan terlalu berlebihan agar tidak menghalangi penyerapan protein dan gizi pada tubuh kita.

7. Otak membutuhkan oksigen yang cukup untuk beraktivitas secara optimal. Hindari tempat-tempat yang memiliki polusi yang tinggi serta tempat yang tercemat udara atau asap beracun. Gunakan masker bila lama melakukan aktivitas di tempat berpolusi atau berasap namun jangan terlalu lama ditutup agar kita tidak keracunan karbondioksida. Perbaiki sirkulasi udara atau ventilasi udara jika ruangan yang ada terasa pengap dan sumpek.

8. Lindungi dan jaga kepala dari benturan atau cedera. Benturan keras di kepala bisa merusak otak kita, oleh karena itu lindungi selalu kepala kita dari benturan.

9. Segera melakukan pemerikasaan ke dokter bila terlihat gejala atau deteksi dini terhadap gangguan orak anak, dan melakukan pengobatan secara maksimal.

10. Melakukan terapi untuk memaksimalkan mutu hidup anak yang memiliki gangguan otak agar dapat lebih memaknai kehidupannya, seperti terapi okupasi, fisioterapi, dan lain-lain. Peran orangtua jelas sangat besar dalam hal ini karena latihan (terapi) harus dilakukan dengan bimbingan dan dukungan orangtua.

\section{Kesimpulan}

Perkembangan otak pada umumnya dipengaruhi oleh faktor genetik dan faktor lingkungan baik lingkungan internal (faktor-faktor yang terdapat dalam diri janin atau anak itu sendiri), maupun lingkungan eksternal (faktor di luar anak). Perkembangan otak anak yang sedang tumbuh melalui tiga tahapan, mulai dari otak primitif (action brain), otak limbik (feeling brain), dan akhirnya ke neocortex (atau disebut juga thought brain, otak pikir). Gangguan perkembangan otak bisa terjadi sejak dalam kandungan sampai dewasa; berlangsung secara akut dan progresif; bisa kronis tidak progresif tetapi terjadi perubahan yang nyata atau subklinis diikuti munculnya gangguan fungsi tergantung penyebabnya.

Penyebab gangguan perkembangan otak masa janin dapat diakibatkan oleh faktor internal dan eksternal dari ibu, yaitu asap rokok, flu berkepanjangan, kekurangan asam folat, infeksi TORCH, 
konsumsi antridepresan, kekurangan yodium, kekurangan vitamin D, dan paparan polusi udara. Gangguan-gangguan perkembangan otak yang dapat dialami anak usia dini yaitu anensefalus, mikrosefalus, ensefalokel, porensefalus, hidranensefalus, hidrosefalus, mielomeningokel, Celebral Palsy, meningitis, kanker otak

\section{Daftar Pustaka}

Wikipedia. Tersedia:http://www.Otak - Wikipedia bahasa Indonesia, ensiklopedia bebas.htm [22-03-2013.] [04-09-2013]

Agus Surono. Tersedia:http://www.Tiga tahap perkembangan otakIntisari Online.htm [Tiga Tahap Perkembangan Otak. [19-072011] [04-09-2013]

John W Santrock. Perkembangan Anak. Jakarta: Erlangga, 2007. H.171-172

Sunartini. Deteksi Gangguan Perkembangan Otak Dan Pengembangan Potensi Anak Dengan Kemampuan Dan Kebutuhan Khusus. Jogjakarta: Universitas Gadjah Mada Press, 2008

Widodo Judarwanto. Tersedia:http://www.gangguan otak netlWaspadai 10 Kondisi Kehamilan Penyebab Gangguan Janin.htm [09-04-2013] [04-09-2013]

Medicastore. Tersedia:http:www.gangguan otak net Informasi Kelainan Otak Bawaan - medicastore.com.htm [2010] [04-092013]

httplgangguan otak netlWaspadai 10 Kondisi Kehamilan Penyebab Gangguan Janin.htm [04-09-2013]. 